\title{
RENCANA STRATEGI PESANTREN SEBAGAI LEMBAGA PENDIDIKAN DI INDONESIA
}

\author{
Darliana Sormin, MA \\ Email: darliana.sormin@um-tapsel.ac.id
}

\begin{abstract}
Islam suffered a setback when confined with taklid and ignored science. When Islam leaves science and experiences stagnation, other nations and nations rise from adversity. Finally, now in some period of time Islam suffered. Therefore it is time for pesantren, madrassas and Islamic schools to lift the fall of the Indonesian people in particular and mankind in general today. The roles of madrassas and scholarship such as Baitul Hikmah in the glory of Islam, which has made significant contributions to the progress of Islam, can be transferred by pesantren, madrasah and Islamic schools to be applied today, so that these three Islamic institutions become science laboratories religious and scientific research activities center.

Keywords: Strategic Plan, Pesantren, Educational Institution
\end{abstract}

\section{A. PENDAhUluan}

Pesantren menurut pengertian dasarnya adalah "tempat belajar para santri", sedangkan pondok berarti "rumah atau tempat tinggal sederhana yang terbuat dari bambu". Di samping itu, "pondok" mungkin juga berasal dari bahasa Arab "fanduk" yang berarti "hotel atau asrama". Ada beberapa istilah yang ditemukan dan sering digunakan untuk menunjuk jenis pendidikan Islam tradisional khas Indonesia atau yang lebih terkenal dengan sebutan pesantren. Di Jawa termasuk Sunda dan Madura, umumnya 
dipergunakan istilah pesantren atau pondok ${ }^{1}$, di Aceh dikenal dengan istilah dayah atau rangkung atau meunasah, sedangkan di Minangkabau disebut surau.

Adapun pengertian secara terminologi, dapat dikemukakan beberapa pendapat yang mengarah pada definisi pesantren. Abdurrahman Wahid, memaknai pesantren secara teknis, a place where santri (student) live, sedangkan Abdurrahman Mas'oed menulis, the word pesantren stems from "santri" which means one who seeks Islamic knowledge. Usually the word pesantren refers to a place where the santri devotes most of his or her time to live in and acquire knowledge.

Sejalan dengan perkembangan global, pendidikan Islam menghadapi tantangan manajerial yang cukup mendasar. Harapan dari berbagai pihak agar pendidikan dikelola dengan pola "industri pendidikan" merupakan salah satu perkembangan yang muncul dalam era kompetitif saat ini. Manajemen pendidikan tidak lagi bisa dianggap sebagai "manajemen sosial" yang bebas dari keharusan pencapaian target dan dikendalikan oleh subyek yang berwawasan "sempit", misalnya dengan pendekatan kekeluargaan seperti yang jumpai di sebagian pesantren di Indonesia. Sesuatu yang dapat dikembangkan mengenai peran madrasah, pesantren bahkan sekolah Islam sekalipun, adalah pada peran strategisnya dalam mengelola pola manajemen strategik yang dapat menghasilkan rumusan (formulasi) dan pelaksanaan (implementasi) rencana-rencana untuk mencapai sasaran-sasaran perusahaan dalam hal ini disebut dengan Madrasah, Pesantren dan Sekolah Islam. $^{2}$

\footnotetext{
${ }^{1}$ Zamakhsyari Dhofier, Tradisi Pesantren, Studi tentang Pandangan Hidup Kiai (Jakarta: LP3ES, 1990), hal. 18.

2 Agus Maulana, MSM dalam Pearce Robinson, Manajemen Strategik, Formulasi, Implementasi dan Pengenalian, (Jakarta: Binarupa Aksara 1997).h.20
} 
Sejarah pondok pesantren merupakan bagian yang tidak terpisahkan dari sejarah pertumbuhan masyarakat Indonesia. Dalam sejarah perjuangan mengusir penjajahan di Indonesia, pondok pesantren banyak memberi andil dalam bidang pendidikan untuk memajukan dan mencerdaskan rakyat. Dengan demikian, pesantren sesungguhnya terbangun dari konstruksi kemasyarakatan dan epistemologi sosial yang menciptakan suatu transendensi atas perjalanan historis sosial. Sebagai center of knowledge, dalam pendakian sosial, pesantren mengalami metamorfosis yang berakar pada konstruksi epistemologi dari variasi pemahaman di kalangan umat Islam. Hal yang menjadi titik penting ialah kenyataan eksistensi pesantren sebagai salah satu pemicu terwujudnya kohesi sosial.

Sebagai lembaga pendidikan tertua di tanah air, sudah sepantasnya pesantren mendapat perhatian dari seluruh elemen masyarakat. Karena histori bangsa dan rakyat Indonesia memiliki hubungan erat dengan pesantren. Bagaimana kualitas pendidikan di pesantren mendapat tempat yang utama dalam masyarakat dan pemerintah. Serta langkah perencanaan strategis apa yang harus dilakukan agar membawa pesantren menjadi lembaga studi penopang kekuatan kita sebagai bangsa.

\section{B. PERENCANAAN STRATEGIK DI PESANTREN}

\section{Basis Kultural Pesantren}

Dalam pertumbuhannya, pondok pesantren telah mengalami beberapa fase perkembangan. Hasil penelitian LP3S Jakarta, telah mencatatkan 5 macam pola fisik pondok pesantren, sebagai berikut. : 
1. Pondok pesantren yang hanya terdiri dari masjid dan rumah Kiai. Pondok pesantren seperti ini masih bersifat sederhana sekali, di mana Kiai masih mempergunakannya untuk tempat mengajar, kemudian santri hanya datang dari daerah sekitar pesantren itu sendiri.

2. Pondok pesantren selain masjid dan rumah Kiai, juga telah memiliki pondok atau asrama tempat menginap para santri yang datang dari daerah-daerah yang jauh.

3. Pola keempat ini, di samping memiliki kedua pola tersebut di atas dengan sistem weton dan sorogan, pondok pesantren ini telah menyelenggarakan sistem pendidikan formal seperti madrasah

4. Pola ini selain memiliki pola-pola tersebut di atas, juga telah memiliki tempat untuk pendidikan ketrampilan, seperti peternakan, perkebunan dan lain-lain.

5. Dalam pola ini, di samping memiliki pola keempat tersebut, juga terdapat bangunan-bangunan seperti: perpustakaan, dapur umum, ruang makan, kantor administrasi, toko, dan lain sebagainya. Pondok pesantren tersebut telah berkembang atau bisa juga disebut pondok pesantren pembangunan.

Menurut Zamakhsyari Dhofir bahwa pesantren digolongkan kecil bila memiliki santri di bawah 1000 orang yang pengaruhnya hanya sebatas kabupaten. Pesantren sedang, memiliki santri antara 1000-2000 orang yang pengaruhnya meliputi beberapa kabupaten. Pesantren besar memiliki santri lebih dari 2000 orang dan biasanya berasal dari beberapa propinsi.. ${ }^{3}$

Pendidikan pesantren adalah pendidikan tertua di Indonesia, hingga saat ini model pendidikan pesantren masih bertahan di tengah-tengah modernisasi pendidikan di luar pesantren itu sendiri. Tetapi, juga harus diakui bahwa pesantren-pesantren yang dulu

\footnotetext{
${ }^{3}$ Wahjoetomo, Perguruan Tinggi Pesantren (Jakarta: Gema Insani Press, 1997), hal. 82.
} 
pernah mengalami kejayaan, sebagian mengalami kesurutan sejarah karena regenerasi para kiainya tidak disiapkan dalam pengkaderan serius. Sementara arus sedemikian kuat terhadap pesantren, justru dunia pesantren tertantang untuk menjawab problematika pendidikan di masyarakat.

Dengan demikian, pesantren sesungguhnya terbangun dari konstruksi kemasyarakatan dan epistemologi sosial yang menciptakan suatu transendensi atas perjalanan historis sosial. Sebagai center of knowledge, dalam pendakian sosial, pesantren mengalami metamorfosis yang berakar pada konstruksi epistemologi dari variasi pemahaman di kalangan umat Islam. Hal yang menjadi titik penting ialah kenyataan eksistensi pesantren sebagai salah satu pemicu terwujudnya kohesi sosial. Keniscayaan ini karena pesantren hadir terbuka dengan semangat kesederhanaan, kekeluargaan, dan kepedulian sosial. Konsepsi perilaku (social behavior) yang ditampilkan pesantren ini mempunyai daya rekat sosial yang tinggi dan sulit ditemukan pada institusi pendidikan lainnya.

Kemampuan pesantren dalam mengembangkan diri dan mengembangkan masyarakat sekitarnya ini dikarenakan adanya potensi yang dimiliki oleh pondok pesantren, di antaranya sebagai berikut.

1. Pondok pesantren hidup selama 24 jam; dengan pola 24 jam tersebut, baik pondok pesantren sebagai lembaga pendidikan keagamaan, sosial kemasyarakatan, atau sebagai lembaga pengembangan potensi umat dapat diterapkan secara tuntas, optimal dan terpadu.

2. Mengakar pada masyarakat; pondok pesantren banyak tumbuh dan berkembang umumnya di daerah pedesaan karena tuntutan masyarakat yang menghendaki 
berdirinya pondok pesantren. Dengan demikian, pondok pesantren dan keterikatannya dengan masyarakat merupakan hal yang amat penting bagi satu sama lain. Kecenderungan masyarakat menyekolahkan anaknya ke pondok pesantren memang didasari oleh kepercayaan mereka terhadap pembinaan yang dilakukan oleh pondok pesantren yang lebih mengutamakan pendidikan agama. ${ }^{4}$

\section{Karakteristik Pesantren}

Ada tiga karakteristik sebagai basis utama kultur pesantren di antaranya sebagai berikut:

\section{Tradisionalisme}

Sebagaimana disinggung di atas bahwa lembaga pendidikan pada umumnya adalah milik atau paling tidak didukung masyarakat tertentu yang cenderung mempertahankan tradisitradisi masa lalu. Sementara itu, dengan tetap menyadari kemungkinan terjadinya kontroversial dalam segi tertentu, kelompok yang dimaksud adalah Nahdhatul Ulama (NU) dan Persatuan Tarbiyah Islam. ${ }^{5}$

Menurut Zamakhsyari Dhofier, pesantren salaf/tradisional adalah lembaga pesantren yang mempertahankan pengajaran kitab-kitab klasik sebagai inti pendidikan. Sistem madrasah ditetapkan hanya untuk memudahkan sistem sorogan yang dipakai dalam lembaga-lembaga pengajian bentuk lama, tanpa mengenalkan pengajaran pengetahuan umum. $^{6}$

Tradisionalisme dalam konteks pesantren harus dipahami sebagai upaya mencontoh tauladan yang dilakukan para ulama shalaf yang masih murni dalam menjalankan ajaran

\footnotetext{
${ }^{4}$ http://www.pesantrenonline/artikel/detailartikel?.php=124

${ }^{5}$ Deliar Noer, Gerakan Modern Islam di Indonesia (Jakarta: LP3ES, 1998), hal. 19-20.

${ }^{6}$ Mastuhu, Dinamika Sistem Pendidikan Pesantren (Jakarta: INIS, 1994), hal. 26.
} 
Islam agar terhindar dari bid'ah, khurafat, takhayul, serta klenik. Hal ini kemudian lebih dikenal dengan gerakan salaf, yaitu gerakan dari orang-orang terdahulu yang ingin kembali kepada al-Qur'an dan Hadis. ${ }^{7}$

Gerakan salaf ini dalam perjalanan sejarahnya telah memberikan sumbangan besar terhadap modernisasi Islam. Gerakan salaf secara sadar menolak anggapan bahwa Islam tidak cocok. Mereka mencari tahu faktor yang menyebabkan ketidakcocokan tersebut, yakni karena taqlid.

2. Pertahanan Budaya (Cultural Resistance)

Mempertahankan budaya dan tetap bersandar pada ajaran dasar Islam adalah budaya pesantren yang sudah berkembang berabad-abad. Sikap ini tidak lain merupakan konsekuensi logis dari modelling. Ide cultural resistance juga mewarnai kehidupan intelektual dunia pesantren. Subjek yang diajarkan di lembaga ini melalui hidayah dan berkah seorang Kiai sebagai guru utama atau irsyadu ustadzin adalah kitab klasik atau kitab kuning, diolah dan ditransmisikan dari satu generasi ke generasi berikut, yang sekaligus menunjukkan keampuhan kepemimpinan Kiai. Isi kitab kuning menawarkan kesinambungan tradisi yang benar.

Karena konsep cultural resistance pula, dunia pesantren selalu tegar menghadapi hegemoni dunia luar. Sejarah menunjukkan bahwa saat penjajah semakin menindas, saat itu pula perlawanan kaum santri semakin keras.

\section{Pendidikan Keagamaan}

Pendidikan pesantren didasari, digerakkan, dan diarahkan oleh nilai-nilai kehidupan yang bersumber pada ajaran Islam. Ajaran dasar ini berkelindan dengan struktur sosial atau realitas sosial yang digumuli dalam hidup sehari-hari.

\footnotetext{
${ }^{7}$ Karel A. Steenbrink, Pesantren, Madrasah, Sekolah (Jakarta: LP3ES, 1986), hal. 29
} 
Dengan demikian, pendidikan pesantren didasarkan atas dialog yang terus-menerus antara kepercayaan terhadap ajaran dasar agama yang diyakini memiliki nilai kebenaran mutlak dan realitas sosial yang memiliki nilai kebenaran relatif. ${ }^{8}$

\section{Kurikulum Pesantren}

Pada sebuah lembaga pendidikan, kurikulum merupakan salah satu komponen utama yang digunakan sebagai acuan untuk menentukan isi pengajaran, mengarahkan proses mekanisme pendidikan, tolok-ukur keberhasilan dan kualitas hasil pendidikan. ${ }^{9}$ Menurut Iskandar W., kurikulum merupakan program pendidikan sekolah yang disediakan untuk siswa. ${ }^{10}$

Kurikulum pesantren dalam hal ini pesantren "salaf" yang statusnya sebagai lembaga pendidikan non-formal, hanya mempelajari agama, bersumber pada kitab-kitab klasik meliputi bidang-bidang studi: Tauhid, Tafsir, Hadis, Fiqh, Ushul Fiqh, Tashawuf, Bahasa Arab (Nahwu, Sharaf, Balagah, dan Tajwid), Mantiq, dan Akhlak, yang kesemuanya dapat digolongkan ke dalam 3 golongan yaitu: 1) kitab dasar, 2) kitab menengah, 3) kitab besar. ${ }^{11}$

Kurikulum dalam jenis pendidikan pesantren berdasarkan tingkat kemudahan dan kompleksitas ilmu atau masalah yang dibahas dalam kitab, jadi ada tingkat awal, tingkat menengah, dan tingkat lanjut. Setiap kitab bidang studi memiliki tingkat kemudahan dan kompleksitas pembahasan masing-masing, sehubungan dengan itu, maka evaluasi

\footnotetext{
${ }^{8}$ Mastuhu, Dinamika Sistem Pendidikan Pesantren (Jakarta: INIS, 1994), hal. 26

${ }^{9}$ Chabib Thoha, Pengembangan Kurikulum PAI untuk Pembentukan Masyarakat Madani, Makalah (Semarang: Fak. Tarbiyah IAIN Walisongo, 1999), hal. 1.

${ }^{10}$ Iskandar Wiryokusumo dan Usman Mulyadi, Dasar-Dasar Pengembangan Kurikulum (Jakarta: Bina Aksara, 1988), hal. 6.

${ }^{11}$ Zamakhsyari Dhofier, Tradisi Pesantren, hal. 34.
} 
kemajuan belajar pada pesantren juga berbeda dengan evaluasi dari madrasah dan sekolah umum.

Karakteristik kurikulum dalam pesantren yang terfokus pada ilmu agama seperti di atas, tidak lepas dari tujuan pondok pesantren itu sendiri. Adapun tujuan pondok pesantren dibagi menjadi dua bagian, sebagai berikut.

\section{Tujuan umum}

Membimbing anak didik untuk menjadi manusia yang berkepribadian Islami yang dengan ilmu agamanya ia sanggup menjadi muballigh Islam dalam masyarakat sekitar melalui ilmu dan amalnya.

\section{Tujuan khusus}

Mempersiapkan para santri untuk menjadi orang alim dalam ilmu agama yang diajarkan oleh Kiai yang bersangkutan, serta mengamalkannya dalam masyarakat. ${ }^{12}$ Dewasa ini, kalangan pesantren (termasuk pesantren salaf) mulai menerapkan sistem madrasati. Kelas-kelas dibentuk secara berjenjang dengan tetap memakai kurikulum dan materi pelajaran dari kitab-kitab kuning, dilengkapi pelatihan ketrampilan seperti menjahit, mengetik, dan bertukang. Sistem ini kurikulumnya masih sangat umum tidak secara jelas dan terperinci. Tetapi, yang jelas semua pelajaran tersebut telah mencakup segala aspek kebutuhan santri dalam sehari semalam. ${ }^{13}$ Kurikulum yang berkaitan dengan materi pengajian berkisar pada ilmu-ilmu agama dengan segala bidangnya seperti disebut sebelumnya. Kendati demikian, tidak berarti ilmu-ilmu keislaman yang diajarkan di pesantren-pesantren sama dan seragam. Pada umumnya, setiap pesantren mempunyai penekanan atau ciri tersendiri dalam hal-hal ilmu yang diberikan. Oleh karena itu, sulit

\footnotetext{
${ }^{12}$ Arifin H.M., Kapita, hal. 248.

${ }^{13}$ Wahjoetomo, Perguruan, hal. 84-85.
} 
bahkan mustahil menyamaratakan sistem dan kurikulum pesantren seperti yang pernah diusulkan.

\section{Sistem Pengajaran Pesantren}

Salah satu ciri tradisi pesantren yang masih kuat dipertahankan di sebagian besar pesantren adalah pengajian kitab salaf. Kitab salaf yang lebih dikenal di kalangan luar pesantren dengan sebutan kitab kuning, merupakan kitab-kitab yang disusun para sarjana Islam abad pertengahan. Kitab-kitab tersebut dalam konteks penyusunan dan awal penyebarluasannya merupakan karya intelektual yang tidak ternilai harganya, dan hanya mungkin disusun oleh ulama jenius dalam tradisi keilmuan dan kebudayaan yang tinggi pada jamannya.

Isi yang disajikan kitab kuning hampir selalu terdiri dari dua komponen; pertama matan dan kedua komponen syarah. Matan adalah isi inti yang akan dikupas oleh syarah. Dalam lay out-nya, matan diletakkan di luar garis segi empat yang mengelilingi syarah. Ciri lain penjilidan kitab-kitab cetakan lama biasanya dengan sistem korasan (karasan), lembaran-lembarannya dapat dipisah-pisahkan sehingga lebih memudahkan pembaca untuk menelaahnya.

Apabila kita menengok media berita surat kabar masa kini adalah menganut sistem korasan. Di kalangan masyarakat, kedudukan kitab kuning saling melengkapi dengan kedudukan Kiai. Kitab kuning merupakan kodifikasi nilai-nilai yang dianut masyarakat pesantren, sementara Kiai adalah personifikasi yang utuh dari sistem yang dianut tadi. ${ }^{14}$

\footnotetext{
${ }^{14}$ Masdar F. Mas'udi, "Mengenal Pemikiran Kitab Kuning”, dalam Dawam Rahardjo (Ed.), Pergulatan Dunia Pesantren (Jakarta: P3M., 1985), hal. 56.
} 
Sistem pendidikan di pesantren pun memiliki watak mandiri, bila dilihat secara keseluruhan bermula dari pengajaran sorogan, di mana seorang Kiai mengajar santrinya yang masih berjumlah sedikit secara bergilir santri per santri. Pada gilirannya murid mengulangi dan menerjemahkan kata demi kata sepersis mungkin seperti apa yang diungkapkan oleh gurunya. Sistem penerjemahan dibuat sedemikian rupa agar murid mudah mengetahui baik arti maupun fungsi kata dalam rangkaian kalimat Arab. Sistem tersebut, murid diwajibkan menguasai cara pembacaan dan terjemahan secara tepat, dan hanya boleh menerima tambahan pelajaran bila telah berulang-ulang mendalami pelajaran sebelumnya. Sistem sorogan inilah yang dianggap fase tersulit dari sistem keseluruhan pengajaran di pesantren karena di sana menuntut kesabaran, kerajinan, ketaatan, dan disiplin pribadi dari murid itu sendiri. Pengajian sorogan lalu diikuti pengajian weton, seorang Kiai duduk di lantai masjid atau beranda rumahnya sendiri membacakan dan menerangkan teks-teks keagamaan dengan dikerumuni oleh santrisantri yang mendengarkan dan mencatat uraiannya itu. Pengajian sorogan masih diteruskan dengan memberi wewenang kepada guru-guru untuk melaksanakannya di bilik masing-masing.

Namun demikan, tiap pesantren tidak mengajarkan kitab yang sama, melainkan kombinasi kitab yang berbeda-beda sehingga banyak Kiai terkenal dengan spesialisasi kitab tertentu. Hal ini karena kurikulum pesantren tidak distandarisasi. Dari perkembangan seperti itulah bahwa pesantren merupakan lembaga khusus dengan pengajaran kitab-kitab kuning sebagai tempat pendidikan yang mengajarkan, mengembangkan dan menyebarkan ilmu agama Islam dengan sistem pengajaran yang 
dilakukan langsung dari bahasa Arab serta berdasarkan pembacaan kitab-kitab klasik karya ulama besar.

\section{Perencanaan Strategis Pesantren}

Dalam menata langkah strategis, pesantren harus bertekad untuk selalu komitmen pada keunggulan dan nilai-nilai dasar keislaman. Namun dalam prekteknya peluang dan tantangan di era kini tampak semakin kompleks. Perubahan social yang cepat dalam skala nasional dan global telah berpengaruh terhadap aspek sosial, politik, ekonomi, hukum, budaya, dan pendidikan. Atas dasar itulah proses pendidikan di pesantren hendaknya berupaya mengkombinasikan antara pendidikan akademik sebagai bentuk transformasi knowledge dan teknologi dengan kurikulum yang terstruktur dengan kurikulum ilmu pengetahuan keislaman yang mampu merespons isu-isu kontemporer. Karena itu pesantren merupakan salah satu ciri keunggulan akademik, tradisi keunggulan akademik akan dijadikan model yang dapat memberikan kontribusi tentang pendidikan pesantren, dimana Al-Quran dan Sunnah dijadikan inspirasi dan aksi bagi pengembangan ilmu pengetahuan dan teknologi untuk tujuan kemanusiaan.

Peran pesantren secara konvensional adalah melakukan proses transfer ilmu agama Islam, mencetak kader-kader ulama', dan mempertahankan tardisi. Dalam perkembangan modern, pesantren, madrasah dan sekolah Islam menghadapi tantangan baru, di mana ketiga lembaga Islam tersebut tidak bisa mengelak dari proses modernisasi itu. Dampak dari modernisasi setidaknya mempengaruhi pesantren, madrasah dan sekolah Islam tersebut dari berbagai aspeknya. Di antaranya adalah sistem kelembagaan, orientasi hubungan kiyai-santri, kepemimpinan dan peran pesantren, madrasah dan sekolah Islam. 
Orientasi peran pesantren, madrasah dan sekolah Islam sangat dipengaruhi oleh faktor internal pesantren, terutama pandangan dunia kiyainya, dan faktor luar, perkembangan dan tuntutan zaman (sebut saja pengaruh globalisasi).

"Globalisasi" adalah kata yang digunakan untuk mengacu kepada "bersatunya" berbagai negara dalam globe menjadi satu entitas. Secara denotatif "globalisasi " berarti perubahanperubahan struktural dalam seluruh kehidupan negara bangsa yang mempengaruhi fundamen-fundamen dasar pengaturan hubungan antar manusia, organisasi-organisasi sosial, dan pandangan - pandangan dunia. ${ }^{15}$ Beberapa pesantren yang awalnya salafiyah, hanya mengajarkan kitab-kitab kuning dan bertujuan mencetak kader ulama', kemudia berubah dengan menawarkan sekolah formal, seperti madrasah atau sekolah, adalah bukti pesantren mengalami perubahan orientasi.

Perubahan ini terutama sekali dipengaruhi oleh faktor internal dan eksternal.

\section{Faktor Internal}

kiyai, yang dalam pesantren tradisional adalah pemilik sekaligus pemimpin absolut dari pesantren tersebut. Persinggungan kiyai-kiyai dengan budaya luar, baik melalui ibadah haji maupun kegiatan lainnya, turut menyumbangkan gagasan pembaruan yang dilakukan kiyai. Para Kiyai mulai beranggapan bahwa santri tidak cukup dibekali dengan pengetahuan agama semata, melainkan harus memiliki tambahan pengetahuan yang bermanfaat bagi kehidupannya ketika terjuan dan kembali kemasyarakat Beberapa pesantren yang membuka sekolah dan madrasah formal.

\section{Faktor Eksternal}

15 Azyumardi Azra dalam Jurnal Pondok Pesantren Mihrab, vol. II No. 2, November 2007 
selain karena gagasan pembaruan kiyai, juga disebabkan karena tuntutan zaman. Oleh karenanya pesantren-pesantren yang membuka sekolah dan madrasah sedikit banyak dipengaruhi oleh kebutuhan masyarakat tentang tenaga profesional yang memiliki akhlak mulia. Pada awal kemerdekaan, negara banyak membutuhkan pegawai negeri sipil. Untuk memenuhi kebutuhan itu, pesantren tidak tinggal diam. Pendirian sekolah dan madrasah adalah bentuk respon pesantren atas kelangkaan pegawai negeri sipil. Pesantren berharap, stock PNS dari lulusan pesantren memiliki kelebihan di bidang akhlaknya dibanding lulusan dari sekolah biasa. ${ }^{16}$

Dalam perkembangan modern seperti saat ini, tuntutan peran pesantren semakin kompleks. Problem-problem sosial ekonomi yang terjadi di masyarakat, seperti masalah disintegrasi, kemiskinan, kemunduran akhlak sudah semakin terbuka dan merajalela di masyarakat. Pesantren diharapkan tidak saja mampu menyelesaikan masalah-masalah yang terkait dengan faham keagamaan, tetapi juga diharapkan dapat terlibat menyelesaikan masalah-masalah sosial tersebut.

Sejauh pengamatan penulis, pesantren yang di dalamnya ada madrasah dan sekolah Islam memiliki peluang dan kesempatan untuk terlibat aktif dalam menuntaskan problemproblem sosial tersebut. Apalagi pesantren tersebut memiliki karakter sosial dan kedekatan emosi dengan masyarakat karena sifat egalitar dan kesahajaannya yang memungkinkannya dapat berinteraksi secara intensif dengan masyarakat. Contoh pesantren Sunan Pandanaran yang bertempat Dusun Candi, Sardonoharja, Ngaglik, Sleman. Tiap bulan sekali terlihat bagaimana antusias masyarakat dari berbagai Kecamatan bahkan Kabupaten di sekitar Daerah Istimewa Yogyakarta juga luar Propinsi

16 Amin Haedari dalam Jurnal Pondok Pesantren Mihrab, vol. II No. 1, Juli 2007,h,34. 
mendatang pengajian Mujahadah Akbar yang contennya adalah syiar Islam dan sekaligus media komunikasi antar masyarakat muslim muslimah dalam rangka mencari solusi penyelesaian problem-problem sosial kehidupan terkini dan penyadaran diri sebagai hamba atau kholifah kepada sang Kholiq.

Dengan demikian, esensi peran strategis pesantren ada dua pokok, yaitu mencetak kader ulama' yang mendalami ilmu agama dan pada saat yang sama mengetahui, terampil, dan peduli terhadap persoalan keummatan. Lulusan Pesantren diharapkan baik agamanya dan pandai menghadapi persoalan umat.

Dengan peran semacam ini, dimungkinkan pesantren, madrasah dan sekolah Islam terlibat maksimal dalam membangun bangsa ini. Melalui pesantren, madrasah dan sekolah Islam, para santri atau siswa belajar ilmu-ilmu agama dan ilmu sosial yang dibutuhkan masyarakat. Bahkan seterusnya pesantren menjadi lembaga pengkaderan bagi santri atau siswa yang kelak siap terjun di masyarakat.

Peran pesantren yang demikian ini sesungguhnya tidak asing lagi di kalangan dunia pesantren, karena dunia pesantren sudah tahu betul bahwa setiap manusia yang ingin sukses harus menguasai ilmu dan inovatif.

Mencermati peran strategis pesantren, madrasah dan sekolah Islam di Indonesia seperti tersebut di atas, diharapkan dapat mengembalikan kejayaan umat Islam yang pernah menyinari dunia dengan ilmunya. Saat itu, Islam menjadi pusat peradaban di mana di tempat lain sedang mengalami kegelapan. Saat negara dan bangsa lain terkungkung dalam kemunduran dan kemiskinan, Islam maju meninggalkan negara dan bangsa lain. Kemajuan ini diperoleh karena perhatian serius Islam terhadap pengembangan ilmu pengetahuan, disamping tetap mempertahankan ilmu agama. Saat 
itu, tidak ada dikotomi ilmu agama dan umum. Para cendekiawan muslim mempelajari dan menguasai kedua ilmu ini secara bersamaan.

Buku Ibnu Sina tentang kedokteran "Althib", tidak saja dirujuk oleh ilmuwan dan ahli di Barat, tetapi juga menjadi inspirasi bagi perkembangan dunia kedokteran modern. Muhammad Abduh, ahli bidang sosiologi sekaligus pakar bidang agama dan masih banyak lagi sederet cendekiawan muslim dalam berbagai bidang : matematika, bahasa, ilmu tanah, pertanian dan sebagainya yang ikut mencerahkan dunia. ${ }^{17}$

\section{C.PENUTUP}

Islam mengalami kemunduran saat terkungkung dengan taklid dan mengabaikan ilmu pengetahuan. Ketika Islma meninggalkan ilmu pengetahuan dan mengalami kejumudan, negara dan bangsa lain bangkit dari keterpurukan. Akhirnya, kini dalam beberapa kurun waktu Islam mengalami keterpurukan. Oleh karena itu sudah saatnya pesantren, madrasah dan sekolah Islam mengangkat keterpurukan bangsa Indonesia khususnya dan umat manusia pada umumnya saat ini. Peran-peran madrasah dan pundipundi keilmuan seperti Baitul Hikmah pada zaman kejayaan Islam, yang telah memberi sumbangan berarti bagi kemajuan Islam, dapat ditransfer oleh pesantren, madrasah dan sekolah Islam untuk dapat diterapkan saat ini, sehingga ketiga lembaga Islam tersebut menjadi laboratorium ilmu pengetahuan agama dan pusat riset kegiatan ilmiah.

Dengan menjadi pusat riset ilmu pengetahuan, prediksi Nurcholis Madjid, tentang Universitas Tebuireng, Universitas Tremas, Universitas Lirboyo, dan Universitas Pesantren lainnya di Indonesia dapat terwujud. Hal ini cukup beralasan, karena kemajuan Islam masa pertengahan, terutama ditopang oleh budaya riset ilmu pengetahuan. Apalagi

\footnotetext{
${ }^{17}$ Ibid.36
} 
pesantren yang jumlahnya puluhan ribu, jika mampu menjadi pusat riset ilmu pengetahuan, maka pengaruh sekaligus perannya akan melebihi Baitul Hikmah dan dampaknya dapat meluas ke seluruh dunia. Dengan begitu, kemajuan Islam dapat diraih kembali. Lebih dari itu peran pesantren yang utama adalah lulusannya diharapkan memiliki kelebihan dari sisi akhlakul karimah, karena pesantern sudah semestinya menjadi pengawal bagi akhlak yang terpuji ini.

\section{DAFTAR PUSTAKA}

Zamakhsyari Dhofier, Tradisi Pesantren, Studi tentang Pandangan Hidup Kiai, Jakarta: LP3ES, 1990

Agus Maulana, MSM dalam Pearce Robinson, Manajemen Strategik, Formulasi, Implementasi dan Pengenalian, Jakarta: Binarupa Aksara 1997

Wahjoetomo, Perguruan Tinggi Pesantren, Jakarta: Gema Insani Press, 1997 http://www.pesantrenonline/artikel/detailartikel?.php=124 Deliar Noer, Gerakan Modern Islam di Indonesia , Jakarta: LP3ES, 1998 Mastuhu, Dinamika Sistem Pendidikan Pesantren, Jakarta: INIS, 1994 Karel A. Steenbrink, Pesantren, Madrasah, Sekolah, Jakarta: LP3ES, 1986 Mastuhu, Dinamika Sistem Pendidikan Pesantren, Jakarta: INIS, 1994 Chabib Thoha, Pengembangan Kurikulum PAI untuk Pembentukan Masyarakat Madani, Makalah Semarang: Fak. Tarbiyah IAIN Walisongo, 1999 Iskandar Wiryokusumo dan Usman Mulyadi, Dasar-Dasar Pengembangan Kurikulum, Jakarta: Bina Aksara, 1988

Masdar F. Mas'udi, Mengenal Pemikiran Kitab Kuning, dalam Dawam Rahardjo (Ed.), Pergulatan Dunia Pesantren, Jakarta: P3M., 1985

Azyumardi Azra dalam Jurnal Pondok Pesantren Mihrab, vol. II No. 2, November 2007

Amin Haedari dalam Jurnal Pondok Pesantren Mihrab, vol. II No. 1, Juli 2007 
